\title{
PELATIHAN OLAHAN SAWI HIJAU UNTUK MENUMBUHKAN JIWA WIRAUSAHA PADA KELOMPOK WANITA TANI MT AL MUHAJIRIN DI KELURAHAN TAMALANREA JAYA
}

\author{
Khaeriyah Darwis, Andi Rahayu Anwar \\ Fakultas Pertanian Universitas Muhammadiyah Makassar \\ khaeriyah.darwis@unismuh.ac.id
}

\begin{abstract}
Training of the processed green mustard aims to build the entrepreneurship spirit of MT Al Muhajirin mothers with the utilization of processed green mustard food which, if developed to long-term, will foster a productive economy that can increase family income. Also, it is expected later KWT MT Al Muhajirin able to form a Trade Business that produces green mustard chips and ice cream. The activity of dedication to the community of KWT MT Al Muhajirin is done by the method of training in practice and theory. For two days, community members are invited to understand the purpose, benefits, and application of processed green mustard as nutritious food ingredients and economic value. Presentation of learning materials related to the importance of community empowerment through the independent learning process, this group is conducted by the material, objectives and practical benefits of each theme. In the last session, community service activities are presented demonstrations of cooking food, process the green mustard into chips and ice cream is healthy, practical and favored by all walks of life. The process of processing the green mustard greens as raw materials for obtaining these types of food is done by the method of demonstration while providing explanations that must be mastered when will process the green mustard into healthy food for the family, and economic value.
\end{abstract}

Keywords: Entrepreneurship, Green Mustard Processed, Green Mustard ice cream.

\begin{abstract}
Abstrak
Pelatihan olahan sawi hijau ini bertujuan untuk membangun jiwa kewirausahaan ibu-ibu MT Al Muhajirin dengan pemanfaatan olahan pangan sawi hijau yang jika dikembangkan hingga jangka panjang akan menumbuhkan ekonomi produktif yang mampu menambah pendapatan keluarga. Selain itu, diharapkan nanti KWT MT Al Muhajirin mampu membentuk Usaha Dagang yang memproduksi keripik dan es krim Sawi Hijau. Kegiatan pengabdian pada masyarakat KWT MT Al Muhajirin dilakukan dengan metode pelatihan secara praktek dan teori. Selama dua hari bertutur-turut warga masyarakat diajak untuk memahami tujuan, manfaat dan penerapan olahan sawi hijau sehat sebagai bahan olahan makan yang bergizi dan bernilai ekonomi. Penyajian materi pembelajaran yang berkaitan dengan pentingnya pemberdayaan masyarakat melalui proses belajar mandiri, kelompok ini dilakukan sesuai dengan materi, tujuan dan manfaat praktis dari masing-masing tema. Pada sesi terakhir, kegiatan pengabdian pada masyarakat ini disajikan demonstrasi memasak makanan, mengolah sawi hijau menjadi keripik dan es krim yang sehat, praktis dan disukai oleh semua kalangan. Kegiatan mengolah sawi hijau sebagai bahan baku untuk memperoleh jenis-jenis pangan ini dilakukan dengan metode demonstrasi sambil memberikan penjelasan-penjelasan yang harus dikuasai ketika akan mengolah sawi hijau menjadi pangan yang sehat bagi keluarga, dan bernilai ekonomis.
\end{abstract}

Kata Kunci: Kewirausahaan, Olahan Sawi Hijau, Es Krim Sawi Hijau. 


\section{PENDAHULUAN}

\section{Kondisi Umum Kelurahan Tamalanrea Jaya \\ Kelurahan Tamalanrea Jaya} yang berkembang dengan jenis-jenis perumahan memiliki makna positif bagi perkembangan wilayah namun di sisi lain juga berpengaruh terhadap kondisi pengairan dan masalah peresapan air, sehingga di wilayah-wilayah tertentu seringkali terjadi banjir. Dengan beberapa jenis perumahan dibangun di sekitar lahan desa yang semula berupa tanah pertanian, rawa, dan tanah yang tidak terpelihara kini menjadi wilayah yang penuh dengan fasilitas-fasilitas publik dan jasa sehingga penduduk menjadi semakin berkembang. Perkembangan penduduk juga oleh adanya fasilitas pendidikan khususnya perguruan tinggi dan sekolah tinggi yang lokasinya relatif dengan perumahan. Kondisi ini menyebabkan berkembangnya sistem sosial dan ekonomi masyarakat sekitarnya, dengan adanya pemondokan, kontrak atau sewa rumah, layanan jasa, layanan kuliner, serta minimarket yang dibangun di wilayah Tamalanrea Jaya.

\section{Dinamika Sosial Ekonomi Warga Perumahan Bung Permai Kelurahan Tamalanrea Jaya}

Penduduk di Kelurahan

Tamalanrea Jaya khususnya warga Perumahan Bumi Bung Permai merupakan sebuah kompleks perumahan yang begitu beragam kondisinya. Artinya oleh karena perumahan tersebut sudah ada sekitar 20 tahun yang lalu, maka dapat dipastikan perubahan kependudukan juga semakin berusia dewasa, tua atau lansia, dengan status ibu rumah tangga yang waktunya kebanyakan dihabiskan dirumah dan mengikuti kegiatan Majelis Taklim. Kegiatan ibu-ibu majelis taklim ini meliputi kegiatan pengajian dan kegiatan sosial, kerja bakti, pertemuan rutin PKK dan pertemuan antar RT. Dan terkini majelis taklim ini sudah membentuk kelompok tani wanita. Kebutuhan akan peningkatan kualitas kehidupan yang sinergis dengan ketahanan pangan, gizi dan lingkungan yang tertata, bersih dan mencukupi kebutuhan hidup dan keluarga (Rahmawaty dkk, 2012) tampaknya semakin dibutuhkan oleh ibu-ibu rumah tangga di wilayah perumahan ini. Oleh karena itu kegiatan PPM oleh dosen-dosen dan mahasiswa Faperta Unismuh ini diperuntukkan untuk ibu-ibu rumah tangga yang tergabung dalam Majelis Taklim Al Muhajirin sekitar 10 orang yang diasumsikan memiliki kemauan yang keras untuk mengembangkan jiwa kewirausahaan dibidang pertanian khususnya pengolahan pangan komoditi sawi hijau. Hal ini menjadi pilihan karena ibu-ibu ini memiliki hobi memasak, pengolahan sawi hijau yang mudah.

\section{Rumusan Masalah}

(1)Masih adanya kesulitan bagi warga masyarakat untuk menciptakan kondisi perumahan yang bersih, sehat dan bermakna bagi kegiatankegiatan usaha produktif.

(2)Masih adanya warga masyarakat yang belum memiliki pengetahuan dan keterampilan tertentu guna mengisi kegiatan dalam kehidupan sehari-hari secara berkualitas.

(3)Masih adanya warga masyarakat yang memiliki kemauan, kemampuan dan keterampilan usaha namun keterbatasan modal usaha, kemampuan manajemen usaha yang menguntungkan.

(4)Belum optimal dan terfokusnya pembinaan bagi para pelaku usaha kecil yang ada dikawasan 
perumahan.

(5)Belum berkembangnya kemampuan wirausaha dalam melakukan peningkatan kualitas hidup bagi diri, keluarga dan masyarakat sekitarnya khususnya warga masyarakat yang tidak melakukan pekerjaan di luar rumah misalnya ibu rumah tangga ataupun pengangguran.

\section{Tujuan dan Kegunaan}

(1)Membangun gerakan mencintai tubuh dengan mengkonsumsi makanan- makanan yang sehat dan diproduksi sendiri.

(2)Membantu warga untuk memiliki pengetahuan, keterampilan tertentu sebagai bagian dari usaha produktif dan peningkatan kualitas kehidupannya setidaknya bagi pilihan makanan yang sehat dan bergizi.

(3)Membangun jiwa kewirausahaan ibu-ibu MT Al Muhajirin dengan pemanfaatan olahan pangan sawi hijau yang jika dikembangkan hingga jangka panjang akan menumbuhkan ekonomi produktif yang mampu menambah pendapatan keluarga. Selain itu, diharapkan nanti KWT MT Al Muhajirin mampu membentuk Usaha Dagang yang memproduksi keripik dan es krim Sawi Hijau.

\section{METODE PELAKSANAAN}

Agar kegiatan ini menjadi efektif, tercapai tujuan dan memiliki makna dan manfaat bagi para peserta pelatihan, maka kegiatan yang terbagi ke dalam beberapa tahap ini dilakukan dengan metode yang berbeda-beda. Kegiatan pengabdian pada masyarakat KWT MT Al Muhajirin dilakukan dengan metode pelatihan secara praktek dan teori. Selama dua hari bertutur-turut warga masyarakat diajak untuk memahami tujuan, manfaat dan penerapan olahan sawi hijau sehat sebagai bahan olahan makan yang bergizi dan bernilai ekonomi.

Penyajian materi pembelajaran yang berkaitan dengan pentingnya pemberdayaan masyarakat melalui proses belajar mandiri, kelompok ini dilakukan sesuai dengan materi, tujuan dan manfaat praktis dari masingmasing tema.

Pada sesi terakhir, kegiatan pengabdian pada masyarakat ini disajikan demonstrasi memasak makanan, mengolah sawi hijau menjadi keripik dan es krim yang sehat, praktis dan disukai oleh semua kalangan. Kegiatan mengolah sawi hijau sebagai bahan baku untuk memperoleh jenisjenis pangan ini dilakukan dengan metode demonstrasi sambil memberikan penjelasan-penjelasan yang harus dikuasai ketika akan mengolah sawi hijau menjadi pangan yang sehat bagi keluarga, dan bernilai ekonomis.

\section{HASIL DAN PEMBAHASAN}

\section{Pembahasan Kegiatan Pelatihan}

(a) Kegiatan pengabdian pada masyarakat dengan pokok materi mengenai pelatihan olahan sawi hijau dilaksanakan dengan beberapa tahap. Pada tahap pertama adalah rekrutmen peserta dengan melalui para ketua RT dimintai daftar nama peserta yang sekiranya mau, mampu mengikuti kegiatan secara penuh dan terlebih dapat mengembangkan pengetahuan dan keterampilannya pasca pelatihan secara berkesinambungan. Sistem rekrumen ini sangat lazim dilakukan untuk mengawali berbagai kegiatan program pemberdayaan masyarakat. 
(b) Dengan bermitra kerja bersama nara sumber yang kompeten, kegiatan pengabdian pada masyarakat ini menjadi kegiatan lebih menyenangkan, mudah diterima dan berdampak pada peningkatan motivasi untuk melakukan usaha pengolahan sawi hijau, minimal untuk memenuhi kebutuhan diri dan keluarganya saja.

(c) Penyajian pengetahuan dan pelatihan sawi hijau dengan menggunakan metode ceramah, tanya jawab yang berkaitan dengan sawi hijau serta praktek pengolahan pangan yang baik. Metode demonstrasi dan menunjukkan pengolahan sawi hijau menjadi es krim sawi hijau dalam perkembangannya secara konkrit, termasuk pemilihan sawi yang baik dan segar, cara mengolahnya secara tepat.

(d) Penyajian bentuk olahan masakan siap saji dengan bahan dasar sawi hijau berupa es krim (anonim, 2017 digunakan dengan metode ceramah, demonstrasi cara membuat es krim dengan bahan sawi hijau dilengkapi dengan tanya jawab dan kesempatan membuat es krim bersama dan mencicipi hasil masakan secara bersama dengan beberapa resep masakan praktis sesuai permintaan peserta.

(e) Pelatihan kewirasahaan selama 1 hari (teori dan praktek). Dalam waktu sekitar seminggu setelahnya tim pelaksana yang ada di lapangan diminta melakukan kunjungan ke rumah para peserta untuk mengumpulkan informasiinformasi penting berkaitan dengan masalah, kesulitan dalam pengolahan sawi hijau.
Pendampingan oleh tim pelaksana di lapangan ini menjadi awal dari pendampingan sesudahnya. Kegiatan pendampingan dilakukan selama sekitar 2 jam dengan mengumpulkan para peserta setelah seminggu usai pelatihan. Model pendampingan dilakukan dengan metode curah pendapat berbagai informasi demi perkembangan bersama. Ada kemungkinan dalam pendampingan akan dilakukan reedukasi atau merefresh kembali pengetahuannya.

\section{SIMPULAN}

Peningkatan kualitas hidup melalui pelatihan pengolahan sawi hijau yang diselenggarakan di wilayah KWT MT Al Muhajirin Kelurahan Tamalanrea Jaya, khususnya para ibu rumah tangga memperoleh respon yang positif. Para warga masyarakat yang mengikuti pelatihan dan di akhir pelatihan memperoleh modal dan kesempatan untuk mandiri atau kelompok mengembangkan sawi hijau sebagai bahan baku olahan masakan yang sehat untuk keluarga. Oleh karena peangolahan sawi hijau pada akhirnya dapat menjadi media saling membelajarkan, berkomunikasi demi bertambahnya wawasan dan merubah paradigma berpikir dari yang tidak melakukan apa-apa menjadi dapat melakukan aktivitas bahkan memberi layanan yang lebih baik akan kebutuhan makanan sehat bagi keluarganya.

Dengan melakukan aktivitas olahan sawi hijau menjadi olahan pangan tanpa mengganggu lingkungan, juga kesempatan untuk saling berbagi informasi, dan menjadi modal bagi ibuibu rumah tangga untuk mengembangkan usahanya untuk menunjang pendapatan keluarga. Kegiatan pengabdian pada masyarakat yang memberdayakan masyarakat 
Khaeriyah Darwis, dkk. Pelatihan Olahan Sawi Hijau Untuk...

khususnya perempuan memiliki arti bagi perubahan cara berpikir kelompok ibu- ibu peserta PPM. Tindak lanjut kegiatan ini perlu diikuti dengan pendampingan oleh tokoh masyarakat misalnya pengurus PKK khususnya pengembangan jiwa kewirausahaan dalam kegiatan yang terintegrasi dengan program kerja KWT RT, RW setempat. Hal ini digunakan untuk menjamin kelangsungan pola kegiatan yang memberdayakan kaum ibu untuk turut meningkatkan kualitas hidup melalui pola makan yang sehat dalam kebersamaan perumahan yang lebih kondusif.

\section{DAFTAR PUSTAKA}

Anonim. 2017. Resep Olahan Sawi Hijau yang Gurih dan Mudah. Diakses dari kuliner.bacainfo.com pada tanggal 2 Maret 2017.

Rahmawaty, Penny., HY Agus Murdiyastomo., M Lies Endarwati. 2012. Pemberdayaan Usaha Ekonomi Produktif Bagi Masyarakat Miskin di Kota Yogyakarta. Universitas Negeri Yogyakarta. Yogyakarta.

Septiarti, Wisni., Mulyadi., RB Suharta. 2012. Peningkatan Kualitas Kehidupan dengan Pelatihan Kewirausahaan Budidaya Jamur Tiram yang Ramah Lingkungan di $R W V$ Minomartani Ngaglik Sleman. Universitas Negeri Yogyakarta. Yogyakarta. 